\title{
Abuse of Authority in Position and Redemption of Credit Fictitious Apparatus for Civil State (ASN) PD. Bank Perekreditan Rakyat (BPR) Sumber, Cirebon District
}

\begin{abstract}
Kustriyo ${ }^{1}$ and Aryani Witasari ${ }^{2}$
Abstract. Lending procedures are stages that must be passed before anything was decided to disbursed credits. The purpose is to facilitate banks in assessing the feasibility of a loan application. Prospective borrowers other than credit include the applicant's name or the desired customer also lists the number of credits / loans and other types of credit, which in this case is the customer debtors State Civil Apparatus (ASN) which will apply for credit in PD. BPR Sumber Cirebon. ASN in filing the credit of course have to ensure a decree to PD. BPR Sumber and must go through the stages prescribed by the PD. BPR Sumber. However, employees of PD. BPR Sumber in this case Head of Credit and Marketing Division has abused his authority and unfreeze credit by means of fictitious proposed by ASN using fictitious data. Thus resulting in no small loss in PD. BPR Sumber and the act was qualified as a criminal offense Banking. Basic judges in the court verdict should be based on theory and research results related to each other to obtain the maximum results of research and balanced at the level of theory and practice. Since the purpose of the law itself to fairness, expediency and legal certainty.

Keywords: Position; Authority; Fictitious Credit; BPR.
\end{abstract}

\section{Introduction}

Development of business in the current era of increasing along with the changing times. Seeing the development of the business world many emerging and grow more quickly, it is an impact that is characterized by increasing competition competitive. Competition is a thing that can not be avoided when they are in this business sector. The company will perform efforts in all areas to achieve progress in the face of increasingly stringent. Especially in the era of globalization today the company not only have a local competition but also competition at the global level. Countries that have a total population many have high levels of social status are very diverse. circle lower middle income people are the most dominating society countries that have a high population number.

In Black's Law Dictionary, the bank formulated as follows: "An institution, usually incopated, Whose business to receive money on deposit, cash, checks or drafts, discount commercial paper. Make loans, and issue promissory notes payable to bearer know as bank notes "(A financial institution whose businesses receive money from deposits, cash, checks or drafts, discount commercial paper. Giving the loan, and issue promissory notes payable to the shareholder as bank notes). ${ }^{3}$

According to the Law of the Republic of Indonesia Number 10 of 1998 on 10 November on banking, which is referred to bank are: entities that raise funds from the public in the form of savings and channel them to the public in the form of loans and or forms other in order

\footnotetext{
${ }^{1}$ Student of Master of Law, Universitas Islam Sultan Agung Semarang and State Attorney of Cirebon email Koestriyo81@gmail.com

${ }^{2}$ Lecturer of Faculty of Law UNISSULA Semarang

${ }^{3}$ Hermansyah Hukum Perbankan Nasional Indonesia 2011 Kencana Prenada Media Group Printing of 6 Jakarta p. 7.
} 
to improve the standard of living of the people. ${ }^{4}$

In the banking practice in Indonesia there are currently several banks set out in the Banking Act. If you look at the type of banking before exiting the Banking Act number 10 of 1998 with the previous Act No. 14 of 1967, then there are some differences. But the main or principal activities of the bank as a financial institution that collects funds from the public and distribute the funds do not differ from each other. But after exiting the Banking Principal Act No. 7 of 1992 and reaffirmed by the release of Indonesian Act No. 10 of 1998, the banking types consist of Commercial Bank and Bank Perekreditan Rakyat. Bank Perkreditan Rakyat (BPR) is a bank conducting conventional business or based on sharia principles in their activities do not provide services in payment traffic. Meaning here RB activities are much narrower compared with the activities of commercial banks. ${ }^{5}$

Bank Perekreditan Rakyat is a financial institution that engages in banking groups that serve micro, small and medium enterprises, which are governed by Act No. 7 in 1992 and amended by Act No. 10 of 1998. Formerly known as the granary RB village, village banks, Farmers Bank, Commerce Bank or Bank Village Market has not only the function of lending to the micro, small and medium enterprises, but also accept deposits from the public.

PD Bank Perekreditan Rakyat (BPR) Sumber Cirebon stand by West Java Governor Decree No. 7 / PEG / 7.b / KPI / 69 concerning the establishment of Rural Production Work Bank (BKPD) Cirebon and Finance Ministerial Decree No. KEP-629 / KM .17 / 1997 of 12 November 1997 on Rural Production work Bank Amendment (BKPD) into Bank Perekreditan Rakyat (BPR).

PD BPR (Bank Perekreditan Rakyat Regional Company) is a local government-owned banking institutions. Sumber PD.BPR Cirebon provides banking services and the provision of loans to the public, especially in economically weak groups. With the provision of these loans can benefit all parties including the government which is to achieve one of the objectives of national development in the form of public welfare. For banks, the presence of these branches will enlarge and expand the provision of credit, especially to small traders, Civil Administrative State, Army, Police, and private sector employees. For the people, with their branches of the bank will be easier to obtain credit services. Especially in PD. BPR Sumber Cirebon.

In practice, the provision of credit facilities include employees contribute additional collateral in the form of the Decree of the State Civil Apparatus. Participation Decree Apparatus State Civil as an additional guarantee of course, intended to strengthen the position of the bank as credit facilities, this is due to hold an additional guarantee the repayment of credit facilities granted to Apparatus Spil State concerned will precedence over creditors other.

Activities of the bank after collecting funds from the public in the form of demand deposits, savings and time deposits are channeling funds back to communities that need it. This fund distribution activities also known as the allocation of funds. Allocating funds can be realized in the form of a loan or better known as credit. The allocation of funds can be done to buy assets that are considered profitable bank. Credit according to the Banking Act No. 10 of 1998 is the provision of cash or the equivalent, based on agreements between bank lending and other parties who require the borrower to pay off debt after a certain period of time

\footnotetext{
${ }^{4}$ Kasmir Bank \& Lembaga Keuangan Lainnya 2002 PT Raja Grafindo Persada Printing of 6 Jakarta p. 33.

${ }^{5}$ Ibid p.33.
} 
with interest. ${ }^{6}$

Giving credit without first going sangatmembahayakan analyzed bank. Customers in this case easily give fictitious data so that the loan did not deserve to be given. Consequently, if one of the analyzes, the loans will be difficult charged alias jammed. Before a credit facility granted, the bank must be sure that the loans will actually return. The confidence gained from the credit ratings before the credit was disbursed. Credit ratings by banks can be done in various ways to gain the confidence of its customers, such as through the correct procedures. $^{7}$

If the measures taken by the credit breaker on a Bank Perekreditan Rakyat of the criminal acts and that clearly violate the law or procedures to provide credit, it is concerned that in the end people become hesitant in applying for a loan at the People's Bank Perjreditan. Yet on the other hand, the credit provision was needed by the community for the purpose of developing the business and impact on improving the welfare of the community, of course, leads to the ideals of the nation that wants Indonesia as a developed nation and autonomously without debts abroad.

PD. BPR Sumber Cirebon, is one of the government-owned BPR areas that have strict competitors, in addition to commercial banks that are mushrooming in the working area, now private BPR began to emerge. This course requires PD. BPR Sumber Cirebon to create a business by providing services as much as possible in an effort to stay ahead for long-term competitiveness by offering the promise of such an assurance in banking services for its customers. This is because the quality of services can be used as a tool to achieve competitive advantage. With the improvement of quality of service is good then it may cause a customer loyalty, and likely will attract new customers.

To increase public confidence in the PD. BPR Sumber Cirebon is now trying to improve the delivery and quality of products that they have launched, as well as trying to keep the level of bad loans remains low.

Low levels of bad loans or non-performing loans is an indicator that is most easily seen to assess the performance of a BPR. The higher the percentage of bad loans, the lower the performance of the bank, and conversely, the lower the percentage of bad loans, the higher the performance of the people Credit Bank. Non-Performing Loans can be classified into three groups, namely the bank's internal factors, factors and external factors debtor bank. This study used the bank's internal factors as research material, are factors originating from the bank itself.

Based on the above background, the problem is formulated as follows: 1) What is the procedure for credit granting State Civil Apparatus (ASN) in PD Bank Perekreditan Rakyat Sumber Cirebon? 2) Why Occurred Position Abuse and Authority Head of Credit and Marketing Division in extending credit? 3) How Consideration Judge In Abuse Case Breaking Position and Privileges?

\section{Research Methods}

The research method is a way of doing something by thinking carefully to achieve a goal to seek, noting, formulate and analyze up to draw up a report. ${ }^{8}$ Where the author / researcher using sociological juridical research method that examines the applicable law and what

\footnotetext{
${ }^{6}$ Op Cit p. 91.

${ }^{7}$ Loc cit p. 104.

${ }^{8}$ Cholid Narbuko and Abu Achmadi Metode Penelitian 2003 PT. Bumu Aksara Jakarta p.1
} 
happens in reality. ${ }^{9}$

\section{Results and Discussion}

Lending procedures are stages that must be passed before anything was decided to disbursed credits. The purpose is to facilitate banks in assessing the feasibility of a loan application.

The occurrence of a credit agreement with a guarantee of mortgage orDecree of the State Civil Apparatus PD. BPR Sumber Cirebon done in several stages, namely:

- Terms Subjective

- For individual debtor must submit a copy of Identity Card or other proof of identity;

- For employers who apply for credit over Rp. 10,000,000.00 (ten million rupiah) must include No. principal Taxpayer Identification Number (TIN);

- For prospective borrowers the form of business should enclose a copy of a business license;

- For a debtor who is a legal entity must be include a copy of the deed of establishment.

- Term Objective

- No effort should be financed, which include: In a relatively long period of time; Good prospects; In favorable conditions.

- Provide assurance that material in the form of guarantees The land is evidenced by a certificate of ownership on land, and to State Civil Apparatus shall decree of the State Civil Apparatus. Participation Decree of the State Civil Apparatus as an additional guarantee of course, intended to strengthen the position of the bank as credit facilities.

Prospective borrowers other than credit include the applicant's name or the desired customer also lists the number of credits / loans and other types of credit. Wherewhere in this case the debtor client is the State Civil Apparatus (ASN) which will apply for credit in PD. BPR Sumber Cirebon.

With credit application filled it has been provided by bank and attached documents / files needed in requirement, the loan application will be entered into next. This phase also involves the administration, namely selecting files / documents are compliant with administration or not. If the administrative requirements are not complete the loan application will be rejected. Where employees of PD. BPR Sumber Cirebon of the greatest role in this regard is the Head of Credit and Marketing Division who advance through the Credit Committee. Where the application for credit spurned by the Marketing Division collected later in the copy of ID, KK and other documents and subsequently by Section Marketing modify the document by way of shredding fragments of letters / numbers and attached to each other so that it becomes a new data were made completeness credit application file to the PD. BPR Sumber whereas the debtor's signature, The signing of the loan agreement was not carried out at the office of PD BPR Sumber Cirebon but the files application for credit and loan agreements taken by Head of Credit and Marketing Sectionwith reason to be brought to the debtor to be signed by the debtor while the loan guarantees for loan applications, among others such as SK First Officer or Certificate of Ownership or the original Sale and Purchase Agreements were never submitted to the PD

${ }^{9}$ Bambang Waluyo Penelitian Hukum Dalam Praktek 2002 Sinar Grafika Jakarta p.15. 
BPR Sumber Cirebon whereas under Rule Directors PD BPR Sumber No. 854.3 / RB-SB / 72 / XII / 2012 dated December 20, 2012 regarding Guidelines Credit Policy Regional Enterprise Bank Perekreditan Rakyat Sumber, in Article 4 of the Special Requirements of Credit Gobertap / PNS b stated that the approval and disbursement must submit SK First used as collateral, submit original papers agreed. Head of Credit and Marketing Section not in accordance with the terms and conditions applicable to PD BPR Sumber Cirebon so act Head of Credit and Marketing Division credit disbursement has caused carrying in the book of register.

One bank burglary crimes are fictitious credit disbursement which is part of the banking crime. There is no uniform definition of banking crimes, even in Act No. 7 of 1992 as amended by Act No. 10 of 1998 did not provide a specific definition of banking crimes, as well as the definition of crimes against bank fraud. Although it does not provide a definition of the crime of banking, the Banking Act establishes thirteen kinds of crimes regulated from Article 46 to Article 50A.

Bank fraud crime is one form of banking crimes were categorized into white color crime, using banks as a means or targets of crime, by taking funds from a bank that is not right fraudulently and in violation of the provisions of the Banking Act.

Based on the provisions contained in the Banking Act was not all types of banking criminal acts stipulated in the Banking Act, only more emphasis on other forms of criminal acts banking with the bank as a means of committing a crime. In the event that the bank becomes a means of criminal acts of banking, the range and scope of crimes and offenses set out in the Banking Act seemed more emphasis on the issue of licensing, administrative procedures, banking, management of banking by directors, commissioners, employees and affiliated parties, and bank secrecy.

The moral aspect is a major factor of the crime because the crime is itself a form of action that is a-moral or without discretion. Similarly, in the case of a person doing the piercing bank, this action is a form of action that is immoral because it contradicts the moral values that existed in society.

In the Banking Act the draft Criminal Code are the provisions of Article 374, which, when viewed from the glass eyes of praxis can take the form of embezzlement activities, embezzlement credit, mark-up value of the transaction, forgery of signatures, forgery of a medical certificate, reception grativikasi, burglary institute a system of rules, and others. Although it is set in the law, not all companies decided at an early stage to directly submit the case to the legal sphere. Such cases are usually processed internally first.

Consideration of judges is one of the most important aspects in determining the realization of the value of a judge's decision containing equity (ex aequo et bono) and contain legal certainty, in addition, it also contains the benefits to the parties concerned so that consideration of the judge must be addressed carefully, either and carefully. If the judge does not carefully considered, well, and carefully, then the verdict came from consideration of the judge will be canceled by the High Court of the Supreme Court. ${ }^{10}$

Basic court judges in decisions need to be based on theory and research results related to each other to obtain the maximum results of research and balanced at the level of theory and practice. One attempt to achieve legal certainty of justice, where a judge is law enforcement officers through its decision to become a benchmark for the achievement of a

\footnotetext{
${ }^{10}$ Mukti Arto 2004 Praktek Perkara Perdata pada Pengadilan Agama Ed. V Pustaka Pelajar Yogyakarta p.140.
} 
rule of law.

A judge is obliged to uphold the law and justice with impartiality. The judge in giving a justice must first examine the truth of the events submitted to then provide an assessment of the event and connect with applicable law. After that a new judge can pronounce sentence against such events. A judge deemed out to be legal so there should not refuse to investigate and adjudicate an event that is put to him. This is regulated in Article 16 (1) of Act No. 35 of 1999 jo. Act No. 48 of 2009 namely: the court may not refuse to examine and adjudicate a case filed on the grounds that the law does not or less clear, but is obliged to examine and hear.

\section{Closing}

\subsection{Conclusion}

- That one banking crime is melting fictitious credits by using the documents of customers who falsified carried out by rogue elements who know and understand about the mechanism of the transaction and technical network in the bank designated as an object of burglary, this allows their affiliated party (parties in banks) are contributing to conduct bank fraud. Parties that do piercing the bank uses Operandi Modus ranging from forgery of documents, double bookkeeping, embezzlement of clients' money, funds transfer mechanism, to use / misuse of the mechanism procedure $L / C$.

- The judge in the case law consideration decision 221 / Pid.B / 2017 / PN.Sbr, based on consideration of the facts in the trial arising. Furthermore, the judges proved juridical considerations submitted by the Prosecution. Before the judges convict shall first consider the things that are burdensome and relieve the defendant. In this case, the judge declared the charges namely Article 49 paragraph (1) all a, Act No. 10 of 1998 on changes to Act No. 7 of 1992 concerning Banking in conjunction with Article 55 paragraph (1) to 1 in conjunction with Article 64 paragraph (1) of the Criminal Code and Act No. 8 of 1981 on Criminal Procedure law. Since the purpose of the law itself to fairness, expediency and legal certainty.

\subsection{Suggestion}

- Supervision of the provision of credit to the ASN or other clients should be checked against the relevant functions so that the internal control system of credit supply PD Bank Perekreditan Rakyat Sumber Cirebon can run smoothly in accordance with the procedures and rules set by the company.

- There needs to be consideration of the judge in imposing criminal penalties to give the fairest, so that no party dirugkan each other.

\section{Bibliography}

[1] Bambang Waluyo 2002 Penelitian Hukum Dalam Praktek Sinar Grafika Jakarta.

[2] Cholid Narbuko dan Abu Achmadi 2003 Metode penelitian PT. Bumu Aksara Jakarta.

[3] Hermansyah Hukum Perbankan Nasional Indonesia 2011 Kencana Prenada Media Group Printing of ke 6 Jakarta.

[4] Kasmir Bank \& Lembaga Keuangan Lainnya 2002 PT Raja GrafindoPersada Printing of 6 Jakarta.

[5] Mukti Arto 2004 Praktek Perkara Perdata pada Pengadilan Agama Ed. V Pustaka Pelajar Yogyakarta. 